\title{
Dynamic capability: The effect of digital leadership on fostering innovation capability based on market orientation
}

\author{
Sasmoko ${ }^{\text {, Leonardus W Wasono Mihardjo }}{ }^{a^{*}, \text { Firdaus Alamsjah }^{\text {a }} \text { and Elidjen }}{ }^{\text {a }}$
}

${ }^{a}$ Business School, Bina Nusantara University, Jakarta, Indonesia

\section{CH R O N I C L E}

\section{Article history:}

Received: April 20, 2019

Received in revised format: April

282019

Accepted: May 22, 2019

Available online:

May 22, 2019

Keywords:

Digital leadership

Dynamic capabilities

Innovation capability

Market orientation

\section{A B S T R A C T}

Industry 4.0 drives enterprises to transform their capabilities especially in innovation and their capabilities to adapt with dynamic market. The capabilities can be fostered when the leader is oriented towards digital technology and market orientation. The role of digital leadership has gained attention for studies to develop innovation and dynamic capabilities based on market orientation. Studies have been conducted on dynamic capabilities with focus on the strategy, management and economic literature including the understanding of its driving key to success. However, the study on the role of digital leadership on the development of dynamic capability based on innovation capability and market orientation has not been intensively discussed. It is argued that the development of dynamic capability and innovation capability is strongly driven from a combination of digital leadership and market orientation. Data in this study is taken from a survey conducted on 88 Indonesian telecommunication firms as a unit for analyses. The results show that digital leadership had a strong direct and indirect relationship with dynamic capability, however the strong path in developing capability is determined from the development of innovation capability that is driven from digital leadership based on market orientation. The finding reinforces the role of digital leadership as a critical influence on development of dynamic capability. Future studies are suggested to extend the research by exploring the research model to elaborate more on the impact of collaboration, leveraging a larger sample size and better statistical tools. A longitudinal study on the companies that implement the transformation based on dynamic capabilities is also recommended for future studies.

\section{Introduction}

Industry 4.0 requires new capabilities for companies to provide new innovation, especially in its business model. Digital technology provides more flexibility for new players to create new products, market and potentially disrupt the existing businesses. Organizations are required to transform their capabilities by leveraging innovation and gain dynamic capabilities that focus on market orientation (Racela, 2014). Market orientation becomes critical in this disruptive era when the market becomes a lot more complex and dynamic (Christensen, 1997). Market turbulence in the digital era is also called VUCA (Volatility, Uncertainty, Complexity and Ambiguity), which refers to the transformation of firms that enables the sensing of opportunities, seizing the design to enable and innovate, and transforming the organization to have a new paradigm (Sandberg, 2014; Yeow et al., 2018; Chima \& Kasim, 2018) .

* Corresponding author.

E-mail address: mihardjo@gmail.com (L.W.W. Mihardjo) 
For an organization to have dynamic capabilities, the role of leadership takes on an important role (Schoemaker et al., 2018). To navigate change and mitigate risks due to the VUCA impact, the leader would require a long term view and the ability to develop a detailed plan to deal with the complexity. They would also need to be able to learn continuously in practicing proven leadership (Cockburn \& Smith, 2016). This paper contributes to the study on the role and influence of digital leadership on the performance of firms' capabilities for innovation and dynamic capability-based market orientation. It also aims to assess the effective paths of the model transformation in the development dynamic capabilities. Dynamic capability focuses on capability as an enhancement of resource-based view concept as the ability of an organization to adapt to the change that is done by reconfiguring the routine activities (Ambrosini \& Bowman, 2009; Eisenhardt \& Martin, 2000; Teece et al., 1997). However, past studies show no consensus on whether or not the development of dynamic capability has direct or indirect implications on performance. Some studies have found that dynamic capability has an indirect effect on performance through operational performance (Eisenhardt \& Martin, 2000; Helfat \& Peteraf, 2003; Sapienza et al., 2006), while others suggest that dynamic capabilities have a direct influence performance (Deeds et al., 2000; Lin \& Wu, 2014). The development of dynamic capabilities have a broad range of firm operational activities to support business development, innovation and alliance (Schoemaker et al., 2018). Dynamic capability is mostly used for the development of innovation capabilities, especially for business model innovations (Breznik \& Hisrich, 2014; Schoemaker et al., 2018; Wasono et al., 2018). However empirical study on the development dynamic capability based on innovation and market orientation has not been conducted. There is also a lack of studies conducted on the topic of the influence of leadership in a digital context. According to the disruption phenomenon, firms that have innovations based on market orientation have a more sustained competitive advantage (Habtay \& Holmén, 2014). Therefore, it is argued that the development of dynamic capability and innovation management based on market orientation has improved in performance. This leads to the suggestion that it may be better than building innovations and forming dynamic capabilities without taking the market into the large piece of consideration. It is also put forward that the role of leadership, especially digital leadership, has a significant, direct and indirect effect in building innovations in the development of dynamic capabilities. Therefore, this study aims to assess the influence of digital leadership in 'capability-building' in terms of organization behavior (market orientation, innovation management and dynamic capability). This is done in order to have sustainable capabilities in the long run.

\section{Literature Review}

The concept of dynamic capabilities refers to a previous study conducted by Schoemaker (2018). The novelty of this study emphasizes on dynamic capabilities and innovation, however the new variables of market orientation and digital leadership have also been taken into consideration to ensure the digital transformation. The situational analysis based on VUCA drives the organization behavior have more focus on market orientation. Market innovation is part of the organization behavior to have intelligence capability based on market knowledge. The view on market orientation has helped formulate dynamic capabilities in terms of sensing opportunity, seizing the design for innovation and the ability of the organization to transform in order to develop new capabilities. In order for an organization to implement dynamic capabilities, digital leadership should also be taken into consideration as it plays a significant role to ensure the dynamic capabilities of an organization aligns with the market. This also helps the chase for innovation management to achieve the ultimate goal of transformation. The dynamic capability framework based on innovation is demonstrated in Fig. 1. Innovation management provides a broad range of innovations to drive the strategic implementation that consists of product innovation, process innovation, position innovation and paradigm innovation (Tidd, 2015).

\subsection{Market Orientation}

Market orientation is the implementation of marketing concepts related to organization behavior and culture to respond to market change. From an organization perspective, this is done to also align with 
organization activities, which should be transformed to focus more on the market (Narver \& Slater, 1990; Anigbogu \& Nduka, 2014; Chang \& Liang, 2015; Le et al., 2018). In relation to organization behavior, market orientation focuses on the products and services to improve customer value (Gaur et al., 2011; Martelo et al., 2013; Santhi \& Gurunathan, 2014; Anyanwu et al. 2016; Jones Osasuyi \& Mwakipsile, 2017; Mosbah et al., 2017; Malarvizhi et al., 2018). Marketing orientation as the organization's cultural approach emphasizes on the belief and value proposition of organizations to take customers as the first priority (Özşahin et al., 2013). The ability to adapt with customer and market changes is called intelligence capability, which includes intelligence dissemination, intelligence generation and intelligence responsiveness (Amfo et al., 2018; Protcko \& Dornberger, 2014).

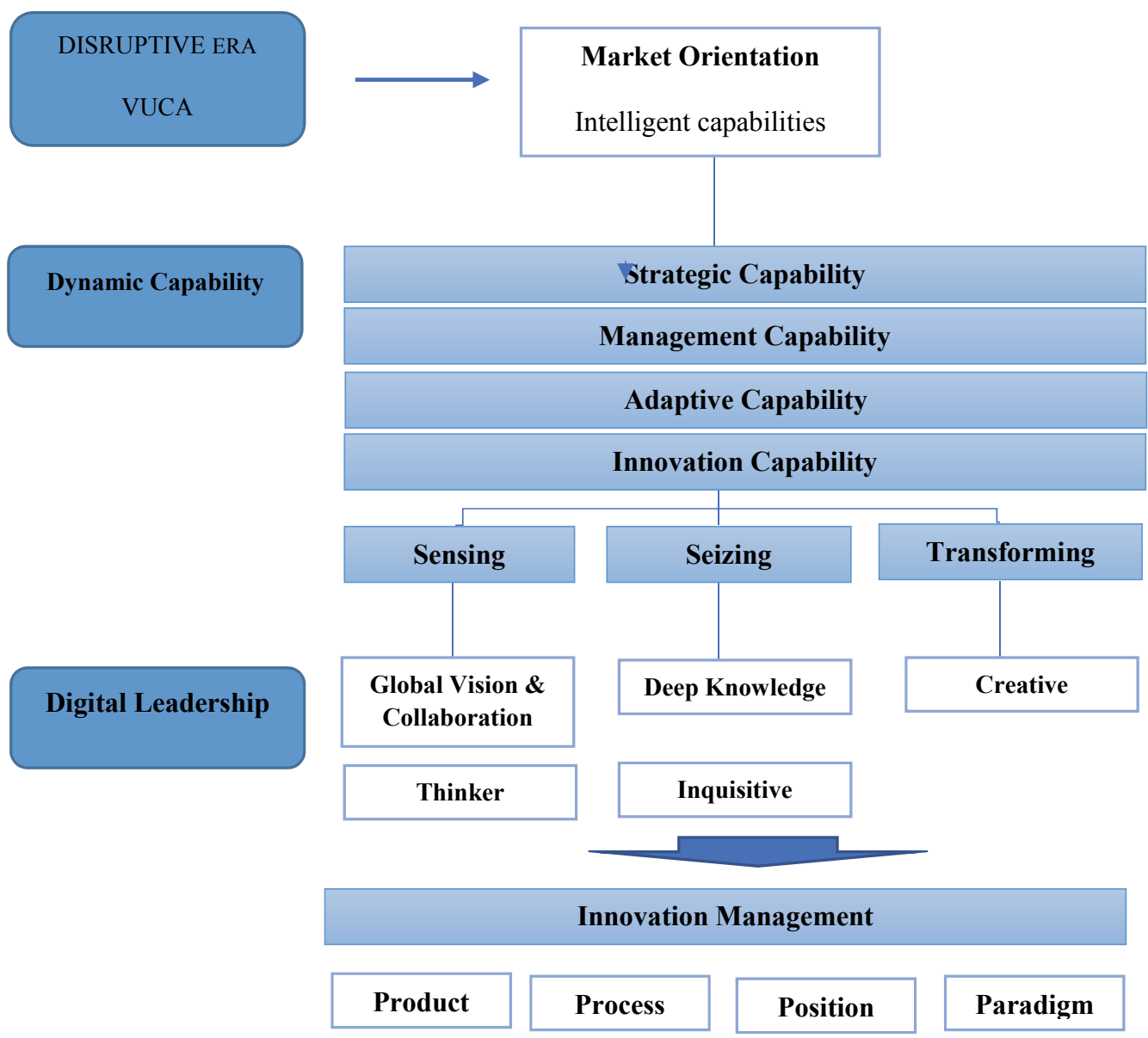

Fig. 1. Dynamic Capability based on Innovation Management

\subsection{Dynamic Capability}

Another capability that is considered as important in resource-based view is dynamic capability. It is defined as the organization's ability to adapt with internal and external changes by transforming existing routine resources, processes, products and services as a part of the new capability (Pisano, 2015; Schoemaker et al., 2018; Teece, 2014). Dynamic capability emphasizes on the resource capabilities of how an organization can be created, extended and modified to align with the changes, up to creating a new paradigm of transformation (Salunke et al., 2011; Purnama, 2014; Chielotam, 2015; Mowlaei, 2017; Albasu \& Nyameh, 2017; Maroofi et al., 2017; Kucukkocaoglu \& Bozkurt, 2018; Maldonado-Guzman et al., 2018). A transformation can be done by integrating, building and reconfiguring the organization's competence as part of sensing, seizing and transforming (Eisenhardt \& Martin, 2000; Teece et al., 1997). The 
development of dynamic capabilities consists of adaptive capability, strategic capability, management capability and innovation capability (Mihardjo \& Rukmana, 2018; Susanti \& Arief, 2015).

\subsection{Digital Leadership}

The combination of leadership competence and the optimized use of digital technology to support decision making called as digital leadership (Goethals et al., 2002). Digital leadership requires an integration of culture and digital competence to utilize digital technology as part of leadership style to bring value to the firm (Mihardjo \& Rukmana, 2018). According to Toduk and Gande (2016), digital leadership has distinctive characteristics, such as (1) creativity, (2) in-depth knowledge (3), strong network and collaboration, (4) and loyal participation via vision. Zhu (2015) also found similar characteristics of digital leadership, suggesting the leadership style to be (1) creative, (2) thinkers, (3) globally visionary and willing to collaborate, are (4) inquisitive leaders and are also (5) profound leaders. Based on these past studies, the digital leadership in this study takes a number of factors into consideration, including creativity, deep knowledge, global vision and collaboration, thinking, inquisition.

\subsection{Innovation Capabilities}

Innovation management consists of a broad range of innovations within four categories: product, process, position and paradigm innovation (Tidd, 2015). Product innovation is the core of innovation that relies heavily on the core competence of the firm and capabilities in order to develop distinct product capability. The process of innovation or technological innovation is also a key enabler to speed up the process of development and decision making through digitization or any innovation that is in a process to enhance performance. Positioning innovation is the innovation on a company's positioning within the market and to adapt with changes and new demands from the market. This includes situations like shifting from a premium segment into low segment positioning. Paradigm innovation is also a part of the business model innovation as a new paradigm of the company.

\subsection{Hypothesis Development}

Leadership has influenced market orientation as part of organization behavior in previous studies as part of organization capability (Menguc et al., 2007; Özşahin et al., 2013) as well as the Indonesian market in the digital era (Mihardjo \& Rukmana, 2018). The hypothesis then can be formulated as the following:

$\mathbf{H}_{1}$ : Digital leadership has a significant impact on market orientation in the Indonesian telecommunication industry.

Leadership contributes significant influence in maintaining innovation management, just as found in other past studies (Schoemaker et al., 2018; Schweitzer, 2014). This finding is also found relevant in the digital era (Mihardjo \& Rukmana, 2018). Based on the findings, the hypothesis is formulated as the following.

$\mathbf{H}_{2}$ : Digital leadership has a significant impact on innovation management in the Indonesian telecommunication industry.

Market orientation has been found as a critical part in enhancing innovation management, especially in business model innovation (Amfo et al., 2018), which is also relevant in the digital era (Mihardjo \& Rukmana, 2018). This leads to the third hypothesis, as following

$\mathbf{H}_{3}$ : Market orientation has a significant impact on innovation management in the Indonesian telecommunication industry.

The role of leadership in developing dynamic capability was found to have significant influence (Schoemaker et al., 2018; Schweitzer, 2014), hence the hypothesis formulation can be stated as the following: 
H4: Digital leadership has a significant impact on dynamic capability in the Indonesian telecommunication industry.

Market orientation has been found as part of the dynamic capability within an organization's behavior (Hou, 2008; Mihardjo \& Rukmana, 2018), hence it is hypothesized that:

H5: Market orientation has a significant impact on dynamic capability in the Indonesian telecommunication industry.

Innovation management has also been found to have significant impact on driving dynamic capability (Breznik \& Hisrich, 2014; Schoemaker et al., 2018), which leads to the following hypothesis:

H6: Innovation capabilities have significant impact on dynamic capabilities within the Indonesian telecommunication industry.

Fig. 2 illustrates the research model of this study

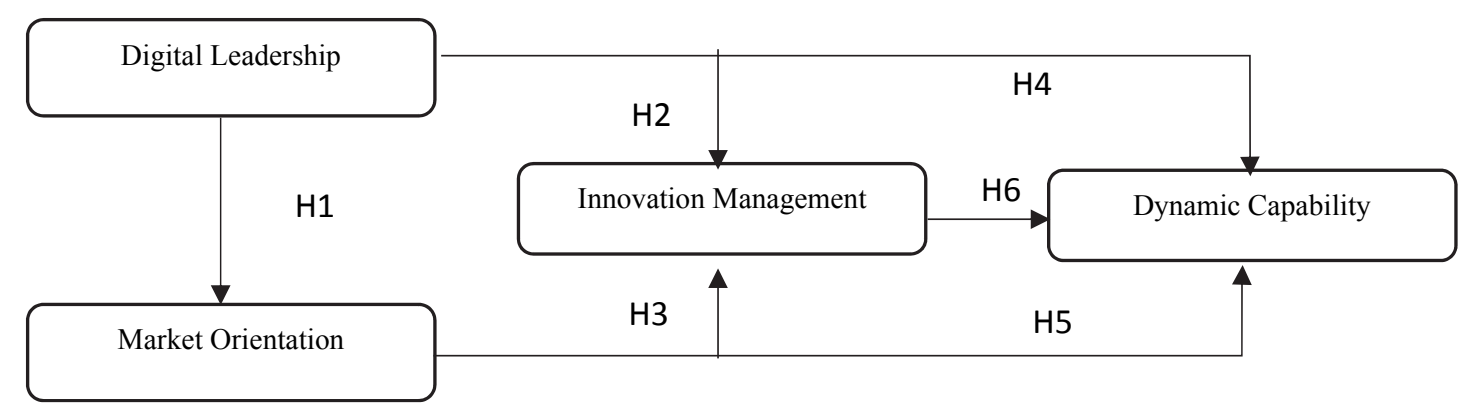

\section{Methodology}

Fig. 2. Research Model

The study was conducted starting November 2017 until January 2018, which was done by observations, interviews, and survey questionnaires. The unit of analysis included Indonesian conventional telecommunication service firms that include the network and service providers. Purposive sampling was used in this study to collect the sampling pool. The required minimum sampling is 52 respondents, as according to Hair et al. (2014), however this study had a sample of 88 respondents which was above the recommended minimum sample size. $75 \%$ of respondents were managers of general manager positions and the rest of $25 \%$ were VP and board leaders. $88 \%$ were men and $12 \%$ were women. $83 \%$ respondents were senior managers from network provider, while $17 \%$ from service providers. Data were collected via self-assessment through an online questionnaire and distributed through messenger, WhatsApp, Telegram and email. SmartPLS was the statistical tool used for analyses considering the latent variables and small sample size.

\section{Results and Findings}

The measurement test is being used to measure the relationship between latent variables and their indicators as well as structural tests to test the hypothesis and model.

\subsection{Evaluation of Measurement}

Validity and reliability are measured based on the following parameters:

- Cronbach alpha to test reliability with minimum threshold of 0.7 ,

- Composite Reliability with minimum threshold of 0.7 ,

- Average Variance Extracted (AVE), expected to be more than 0.5.

The results shown as the following: 
Table 1

Construct's Reliability Test

\begin{tabular}{lcccc}
\hline & Cronbach's Alpha & rho_A & Composite Reliability & AVE \\
\hline Digital leadership & 0.972 & 0.974 & 0.975 & 0.675 \\
Deep Knowledge & 0.913 & 0.916 & 0.939 & 0.794 \\
Global Vision and Collaboration & 0.931 & 0.933 & 0.951 & 0.830 \\
Inquisitive & 0.945 & 0.946 & 0.960 & 0.858 \\
Thinker & 0.915 & 0.915 & 0.946 & 0.854 \\
Creative & 0.872 & 0.875 & 0.912 & 0.723 \\
\hline Market Orientation & 0.951 & 0.956 & 0.956 & 0.553 \\
Intelligent Dissemination & 0.791 & 0.821 & 0.866 & 0.622 \\
Intelligent Generation & 0.876 & 0.879 & 0.907 & 0.619 \\
Responsiveness & 0.920 & 0.927 & 0.935 & 0.646 \\
\hline Innovation Management & 0.959 & 0.961 & 0.966 & 0.780 \\
Product Innovation & 0.837 & 0.844 & 0.924 & 0.859 \\
Process Innovation & 0.941 & 0.941 & 0.971 & 0.944 \\
Position Innovation & 0.906 & 0.906 & 0.955 & 0.914 \\
Paradigm Innovation & 0.855 & 0.862 & 0.932 & 0.873 \\
\hline Dynamic Capabilities & 0.959 & 0.962 & 0.964 & 0.657 \\
Adaptive Capabilities & 0.917 & 0.918 & 0.948 & 0.858 \\
Innovation Capability & 0.817 & 0.826 & 0.892 & 0.734 \\
Management Capabilities & 0.915 & 0.922 & 0.940 & 0.797 \\
Strategic Capability & 0.851 & 0.865 & 0.900 & 0.694 \\
\hline
\end{tabular}

Table 2

The results of outer loading

\begin{tabular}{|c|c|c|c|c|c|}
\hline & Path & SD & T-value & P Values & Conclusions \\
\hline AC1 $\leftarrow$ Adaptive Capabilities & 0.952 & 0.011 & 82.891 & 0.000 & Valid \\
\hline AC2 $\leftarrow$ Adaptive Capabilities & 0.923 & 0.019 & 48.640 & 0.000 & Valid \\
\hline AC $3 \leftarrow$ Adaptive Capabilities & 0.903 & 0.028 & 32.133 & 0.000 & Valid \\
\hline IC1 $\leftarrow$ Innovation Capability & 0.891 & 0.025 & 36.029 & 0.000 & Valid \\
\hline IC2 $\leftarrow$ Innovation Capability & 0.894 & 0.022 & 41.556 & 0.000 & Valid \\
\hline IC3 $\leftarrow$ Innovation Capability & 0.780 & 0.060 & 12.906 & 0.000 & Valid \\
\hline ID1 $\leftarrow$ Intelligent Dissemination & 0.595 & 0.095 & 6.295 & 0.000 & Valid \\
\hline ID2 $\leftarrow$ Intelligent Dissemination & 0.842 & 0.041 & 20.715 & 0.000 & Valid \\
\hline ID3 $\leftarrow$ Intelligent Dissemination & 0.887 & 0.028 & 31.181 & 0.000 & Valid \\
\hline ID4 $\leftarrow$ Intelligent Dissemination & 0.798 & 0.048 & 16.561 & 0.000 & Valid \\
\hline IG1 $\leftarrow$ Intelligent Generation & 0.771 & 0.048 & 16.014 & 0.000 & Valid \\
\hline IG2 $\leftarrow$ Intelligent Generation & 0.746 & 0.058 & 12.753 & 0.000 & Valid \\
\hline IG3 $\leftarrow$ Intelligent Generation & 0.841 & 0.031 & 27.055 & 0.000 & Valid \\
\hline IG4 $\leftarrow$ Intelligent Generation & 0.757 & 0.043 & 17.462 & 0.000 & Valid \\
\hline IG5 $\leftarrow$ Intelligent Generation & 0.801 & 0.053 & 15.132 & 0.000 & Valid \\
\hline IG6 $\leftarrow$ Intelligent Generation & 0.800 & 0.039 & 20.293 & 0.000 & Valid \\
\hline IP1 $\leftarrow$ Process Innovation & 0.971 & 0.010 & 92.826 & 0.000 & Valid \\
\hline IP2 $\leftarrow$ Process Innovation & 0.972 & 0.010 & 98.294 & 0.000 & Valid \\
\hline IP3 $\leftarrow$ Product Innovation & 0.935 & 0.011 & 81.542 & 0.000 & Valid \\
\hline IPAR1 $\leftarrow$ Paradigm Innovation & 0.942 & 0.016 & 59.068 & 0.000 & Valid \\
\hline IPAR2 $\leftarrow$ Paradigm Innovation & 0.927 & 0.028 & 32.930 & 0.000 & Valid \\
\hline IPOS1 $\leftarrow$ Position Innovation & 0.956 & 0.011 & 83.780 & 0.000 & Valid \\
\hline IPOS2 $\leftarrow$ Position Innovation & 0.956 & 0.010 & 92.708 & 0.000 & Valid \\
\hline IPRO1 $\leftarrow$ Product Innovation & 0.919 & 0.022 & 41.209 & 0.000 & Valid \\
\hline IT1 $\leftarrow$ Inquisitive & 0.917 & 0.020 & 45.557 & 0.000 & Valid \\
\hline IT2 $\leftarrow$ Inquisitive & 0.940 & 0.019 & 50.067 & 0.000 & Valid \\
\hline IT3 $\leftarrow$ Inquisitive & 0.903 & 0.021 & 43.774 & 0.000 & Valid \\
\hline IT4 $\leftarrow$ Inquisitive & 0.946 & 0.016 & 60.535 & 0.000 & Valid \\
\hline K1 $\leftarrow$ creative & 0.756 & 0.040 & 18.979 & 0.000 & Valid \\
\hline $\mathrm{K} 2 \leftarrow$ creative & 0.910 & 0.020 & 45.002 & 0.000 & Valid \\
\hline $\mathrm{K} 3 \leftarrow$ creative & 0.864 & 0.043 & 19.899 & 0.000 & Valid \\
\hline $\mathrm{K} 4 \leftarrow$ creative & 0.865 & 0.048 & 17.938 & 0.000 & Valid \\
\hline $\mathrm{MC} 1 \leftarrow$ Management Capabilities & 0.919 & 0.018 & 51.498 & 0.000 & Valid \\
\hline MC2 $\leftarrow$ Management Capabilities & 0.862 & 0.033 & 26.300 & 0.000 & Valid \\
\hline MC3 $\leftarrow$ Management Capabilities & 0.881 & 0.032 & 27.620 & 0.000 & Valid \\
\hline MC4 $\leftarrow$ Management Capabilities & 0.909 & 0.021 & 43.944 & 0.000 & Valid \\
\hline P1 $\leftarrow$ Thinker & 0.916 & 0.017 & 53.401 & 0.000 & Valid \\
\hline $\mathrm{P} 2 \leftarrow$ Thinker & 0.930 & 0.014 & 64.285 & 0.000 & Valid \\
\hline $\mathrm{P} 3 \leftarrow$ Thinker & 0.927 & 0.020 & 47.344 & 0.000 & Valid \\
\hline
\end{tabular}


Table 2

The results of outer loading (Continued)

\begin{tabular}{|c|c|c|c|c|c|}
\hline & Path & SD & T-val. & P Values & Conclusions \\
\hline PM1 $\leftarrow$ Deep Knowledge & 0.844 & 0.035 & 23.957 & 0.000 & Valid \\
\hline PM2 $\leftarrow$ Deep Knowledge & 0.901 & 0.026 & 34.698 & 0.000 & Valid \\
\hline PM3 $\leftarrow$ Deep Knowledge & 0.913 & 0.018 & 51.122 & 0.000 & Valid \\
\hline PM4 $\leftarrow$ Deep Knowledge & 0.905 & 0.023 & 39.757 & 0.000 & Valid \\
\hline R1 $\leftarrow$ Responsiveness & 0.768 & 0.050 & 15.255 & 0.000 & Valid \\
\hline $\mathrm{R} 2 \leftarrow$ Responsiveness & 0.873 & 0.037 & 23.778 & 0.000 & Valid \\
\hline $\mathrm{R} 3 \leftarrow$ Responsiveness & 0.698 & 0.071 & 9.844 & 0.000 & Valid \\
\hline $\mathrm{R} 4 \leftarrow$ Responsiveness & 0.899 & 0.024 & 37.126 & 0.000 & Valid \\
\hline R5 $\leftarrow$ Responsiveness & 0.871 & 0.034 & 25.824 & 0.000 & Valid \\
\hline R6 $\leftarrow$ Responsiveness & 0.777 & 0.062 & 12.600 & 0.000 & Valid \\
\hline R7 $\leftarrow$ Responsiveness & 0.830 & 0.049 & 16.847 & 0.000 & Valid \\
\hline R8 $\leftarrow$ Responsiveness & 0.687 & 0.093 & 7.374 & 0.000 & Valid \\
\hline SC1 $\leftarrow$ Strategic Capability & 0.879 & 0.022 & 40.140 & 0.000 & Valid \\
\hline SC2 $\leftarrow$ Strategic Capability & 0.902 & 0.023 & 39.611 & 0.000 & Valid \\
\hline SC3 $\leftarrow$ Strategic Capability & 0.771 & 0.050 & 15.398 & 0.000 & Valid \\
\hline SC4 $\leftarrow$ Strategic Capability & 0.771 & 0.063 & 12.229 & 0.000 & Valid \\
\hline VG1 $\leftarrow$ Global Vision and Collaboration & 0.925 & 0.021 & 43.438 & 0.000 & Valid \\
\hline VG2 $\leftarrow$ Global Vision and Collaboration & 0.921 & 0.019 & 49.004 & 0.000 & Valid \\
\hline VG3 $\leftarrow$ Global Vision and Collaboration & 0.879 & 0.051 & 17.165 & 0.000 & Valid \\
\hline VG4 $\leftarrow$ Global Vision and Collaboration & 0.918 & 0.017 & 53.664 & 0.000 & Valid \\
\hline
\end{tabular}

Table 1 and Table 2 show that all variables and dimensions had a Cronbach-Alpha, Rho A, composite reliability and AVE above the threshold, hence all variables and dimensions are valid and reliable.

\subsection{Structural Model (Inner Model)}

The blindfolding results show that the Q2 for the innovation management has a score of 0.512 and market orientation with a score of 0.288 . This means that the structural model has adequate predictive relevance with the complete figure of the research model that is demonstrated in Fig. 3.

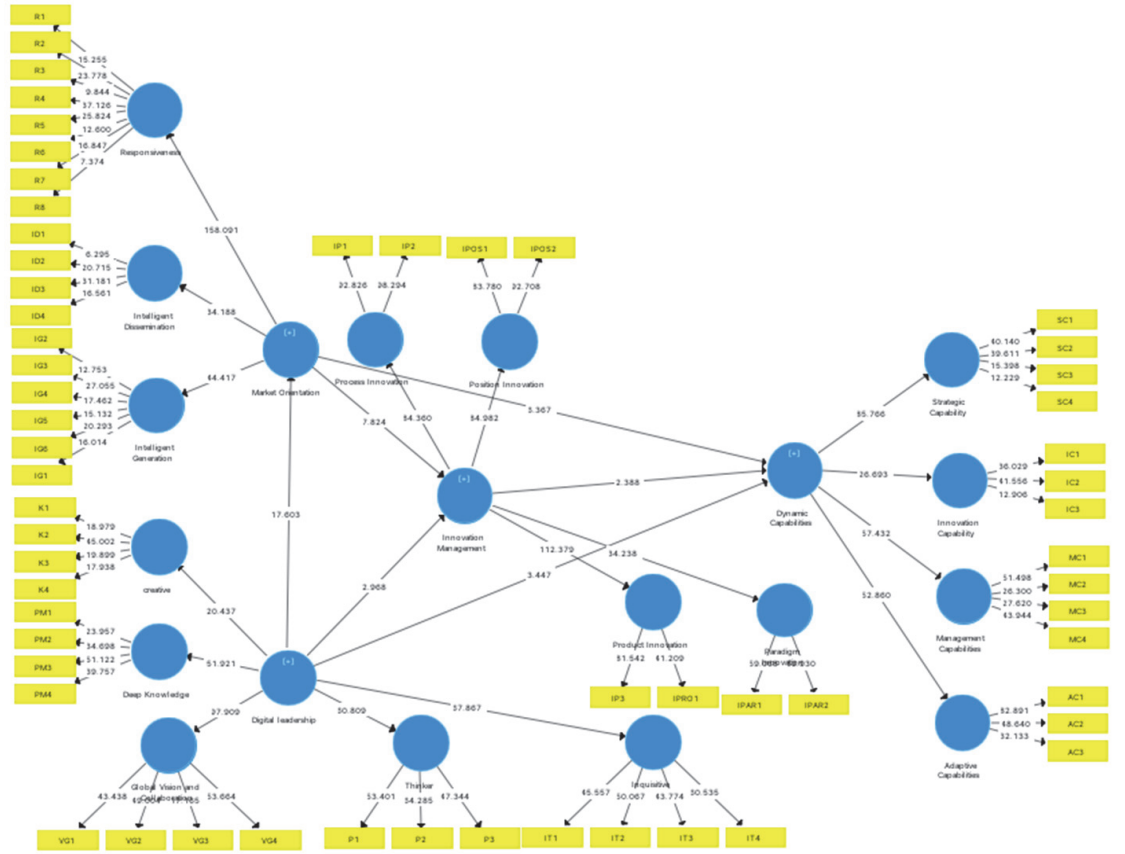

Fig 3. The Complete Research Model

\subsection{Hypothesis Testing}

Partial hypothesis testing was conducted to measure the significance of the direct relationship between variables. Results of the partial testing is demonstrated in Table 3. 
Table 3

Partial Hypothesis Testing

\begin{tabular}{lccccc}
\hline & Path & $\begin{array}{c}\text { Standard } \\
\text { Deviation }\end{array}$ & T Statistics & P Values & Remarks \\
\hline Innovation Management $\rightarrow$ Dynamic Capabilities & 0.186 & 0.078 & 2.388 & 0.017 & Supported \\
Digital leadership $\rightarrow$ Innovation Management & 0.262 & 0.088 & 2.968 & 0.003 & Supported \\
Digital leadership $\rightarrow$ Dynamic Capabilities & 0.229 & 0.066 & 3.447 & 0.001 & Supported \\
Digital leadership $\rightarrow$ Market Orientation & 0.754 & 0.043 & 17.603 & 0.000 & Supported \\
Market Orientation $\rightarrow$ Innovation Management & 0.627 & 0.080 & 7.824 & 0.000 & Supported \\
Market Orientation $\rightarrow$ Dynamic Capabilities & 0.576 & 0.090 & 6.367 & 0.000 & Supported \\
\hline
\end{tabular}

Table 3 shows that digital leadership has a significant, direct influence on market orientation, innovation management, and dynamic capability. While market orientation has a direct influence on innovation management and dynamic capability, innovation management has significant influence on dynamic capability, indicated by the t-statistic value higher than 1.96 and $p$-value is less than 0.05 . Simultaneous hypothesis testing was conducted to assess the indirect effect of independent variables on dependent variables. The results can be seen in Table 3 .

Table 4

Simultaneous Hypothesis Testing Result

\begin{tabular}{lccccc}
\hline & Path & SD & T-Statistics & P-Values & Remarks \\
\hline Digital leadership $\rightarrow$ Market Orientation $\rightarrow$ Innovation Management & 0.473 & 0.062 & 7.652 & 0.000 & Supported \\
Digital leadership $\rightarrow$ Innovation Management $\rightarrow$ Dynamic Capabilities & 0.049 & 0.026 & 1.845 & 0.065 & Not Supported \\
& & & & & \\
$\begin{array}{l}\text { Digital leadership } \rightarrow \text { Market Orientation } \rightarrow \text { Innovation Management } \rightarrow \text { Dy- } \\
\text { namic Capabilities }\end{array}$ & 0.088 & 0.041 & 2.170 & 0.030 & Supported \\
Digital leadership $\rightarrow$ Market Orientation $\rightarrow$ Dynamic Capabilities & 0.434 & 0.072 & 6.023 & 0.000 & Supported \\
\hline
\end{tabular}

Table 4 demonstrates that digital leadership has a strong influence on dynamic capability indirectly through market orientation. Even though innovation management has direct influence on dynamic capability, simultaneous testing of the hypothesis shows that the path of digital leadership does not have significant influence on dynamic capabilities through innovation management. This is indicated by the t-statistics value of less than 1.96 and p-value higher than 0.05 .

\subsection{Discussion and Implications}

The current study findings support Loucks et al. (2015) on the agility issue for incumbent firms to align with market orientation due to legacy and risk taking management. It also supports the issues faced by incumbent firms in facing the disruptive era where market orientation plays a significant role in creating dynamic capabilities (Christensen, 1997; Markides, 2006). Simultaneous testing of the hypotheses shows that marketing orientation supports the innovation management more in order to perform dynamic capabilities, compared to digital leadership-innovation management - dynamic capability. This is because in this case, digital leadership does not fully support innovation management to have dynamic capabilities. In the long run, incumbent firms should develop dynamic capabilities based on innovation managementbased market orientation. The development of dynamic capabilities is emphasized by strong adaptive capability and management capability decisions. This finding supports the previous study on how dynamic capability could enable an organization innovation to sense market changes in detecting the weak signals, seize opportunities and threats to develop scenarios and mitigate potential risks. It could also transform the new paradigm and reshape the environment to navigate the dynamic capability to be more agile in the turbulence environment (Schoemaker et al., 2018; Teece et al., 1997) 
In the digital era, navigating in a dynamic and VUCA environment requires special leadership that combines leadership capabilities and optimizes the use of digital technology as a part of the opportunity to enhance the top line and mitigate threats. Leaders must develop the individual capacity and competence to better manage uncertainties and lead organizations to adapt with strong dynamic capabilities. Leaders have to define the vision and growth lead towards the vision in the future. Findings of the study align with the phenomenon where the most important factor in digital leadership is global vision and collaboration followed by thinking and deep knowledge. This finding also supports Schoemaker et al. (2018) and Zhu (2015). Thinking and inquisition are related to the challenges and interpretations of the leaders to be able to sense market change and support the seizing of opportunities, as well as mitigating potential threats out of curiosity. The next capability that is required from digital leadership is deep knowledge, which is related to decision making based on the knowledge to provide digital technology support. Indepth knowledge is also demonstrated the leaders' continuous learning. The last capability is creativity, which is a very important capability in order to be able to unleash numerous business model innovations, especially in the digital era. The emergence of Internet of things (IoT) has enabled the connection of all industry parties. The combination of collaboration and virtual connectivity could effectively mutate a new paradigm and form a remarkable innovation. For incumbent telecommunication firms in Indonesia, digital leadership is central to dynamic capabilities in the development of innovation. Innovation design and implementation should align with the market while also contributing transactions to the firm. The transactional trigger in relation to the experience for customers to transform new capabilities for incumbent firms are demonstrated in Fig. 4 (Kapmeier \& Struben, 2017).

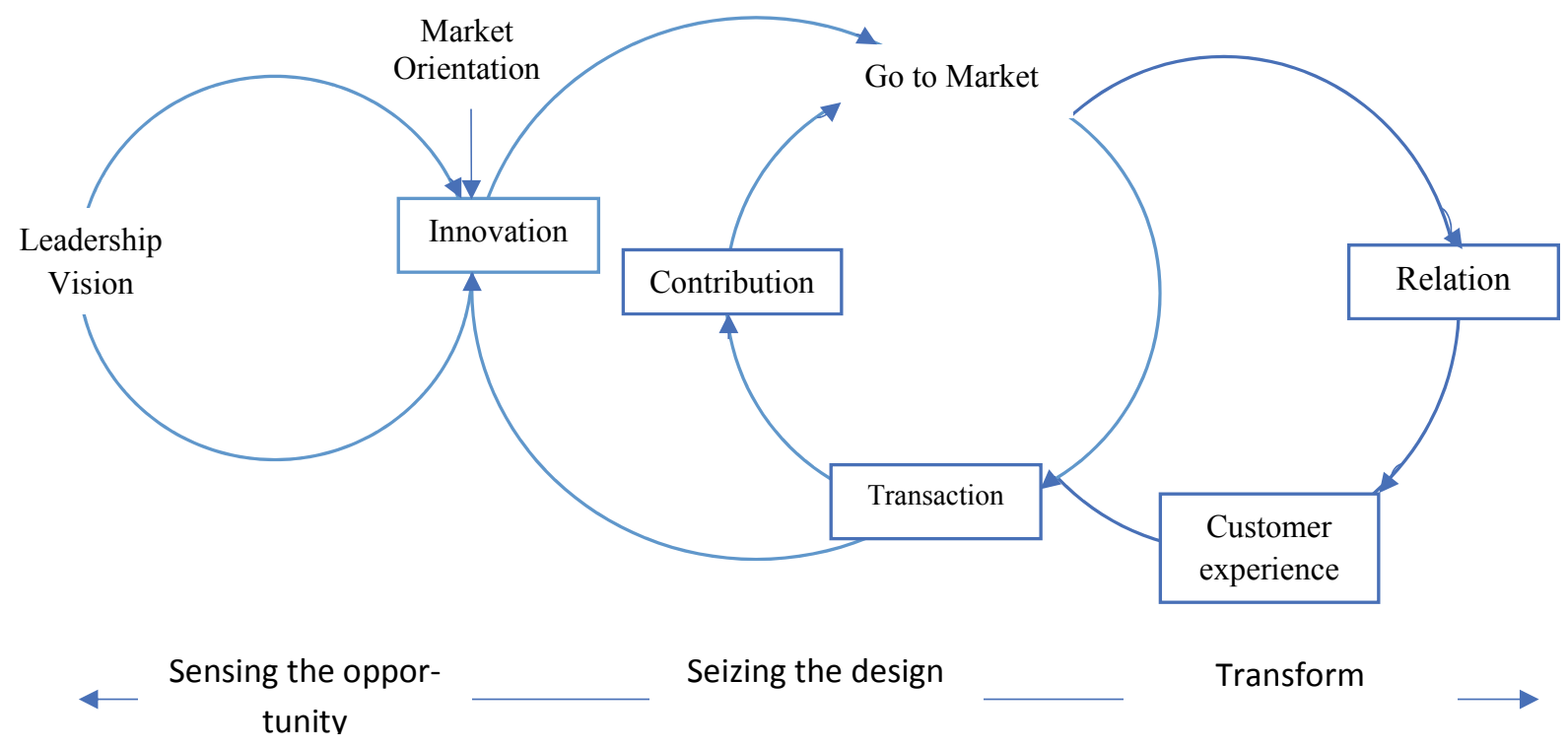

Fig. 4. Dynamic Capability on Innovation

(Kapmeier \& Struben, 2017)

\section{Conclusion}

Digital leadership has a significant influence in driving market orientation, innovation management, and dynamic capabilities. However, the most important factor in developing innovation management should rely heavily on the market to support a form of dynamic capability. This study has limitations in terms of the sample size, methodology, length, and research model, therefore future studies are suggested to expand the study by taking samples from countries other than Indonesia and in industries other than ICT, since the research model can be applicable across different countries and industries. It is also recommended for future studies to use a larger sample size and more advanced statistical tool for analyses. Other than that, a longitudinal study design should also be conducted to be able to have a better examination on the long-term effects of digital leadership. 


\section{References}

Albasu, J., \& Nyameh, J. (2017). Relevance of stakeholders theory, organizational identity theory and social exchange theory to corporate social responsibility and employees performance in the commercial banks in Nigeria. International Journal of Business, Economics and Management, 4(5), 95-105.

Ambrosini, V., \& Bowman, C. (2009). What are dynamic capabilities and are they a useful construct in strategic management? International Journal of Management Reviews, 11(1), 29-49.

Amfo, P., Cudjoe, G., Acheampong, G., Adams, M., \& Boakye, E. (2018). Market orientation, innovation and business performance: Insight from womenpreneurs in the fashion industry in Ghana market orientation. Journal of Creativity and Business Innovation, 4.

Anigbogu, U. E., \& Nduka, E. K. (2014). Stock market performance and economic growth: Evidence from Nigeria employing vector error correction model framework. The Economics and Finance Letters, 1(9), 90-103.

Anyanwu, J. O., Okoroji, L. I., Ezewoko, O. F., \& Nwaobilor, C. A. (2016). The impact of training and development on workers performance in Imo State. Global Journal of Social Sciences Studies, 2(2), 51-71.

Breznik, L., \& Hisrich, R. D. (2014). Dynamic capabilities vs. innovation capability: are they related? Journal of Small Business and Enterprise Development, 21(3), 368-384.

Chang, W. S., \& Liang, C. (2015). Exploring potential entrants' perceptions of the performance of an agrirural social enterprise in Taiwan. International Journal of Management and Sustainability, 4(10), 205-217.

Chielotam, A. N. (2015). Oguamalam Masquerade performance beyond aesthetics. Humanities and Social Sciences Letters, 3(2), 63-71.

Chima, P., \& Kasim, U. (2018). Public-private partnership as a strategy for e-governance funding in Africa: The gains and the pains. International Journal of Public Policy and Administration Research, $5(2), 37-47$.

Christensen, C. M. (1997). The Innovator's Dilemma: When New Technologies Cause Great Firms to Fail. Boston, MA: Harvard Business School Press.

Cockburn, T., \& Smith, P. A. C. (2016). VUCA and the power of Emergence Teams. PM World Journal, $5(8), 1-13$.

Deeds, D. L., DeCarolis, D., \& Coombs, J. (2000). Dynamic capabilities and new product development in high technology ventures: An empirical analysis of new biotechnology firms. Journal of Business Venturing, 15(3), 211-229.

Eisenhardt, K. M., \& Martin, J. A. (2000). Dynamic capabilities: What are they? Strategic Management Journal, 21(1), 1105-1121.

Gaur, S. S., Vasudevan, H., \& Gaur, A. S. (2011). Market orientation and manufacturing performance of Indian SMEs: Moderating role of firm resources and environmental factors. European Journal of Marketing, 45(7), 1172-1193.

Goethals, G. R., Sorenson, G. J., \& Burns, J. M. (2002). Leadership in the Digital Age in Encyclopedia of Leadership. Thousand Oaks, Califronia: Sage Publications.

Habtay, S. R., \& Holmén, M. (2014). Incumbents' responses to disruptive business model innovation: the moderating role of technology vs. market-driven innovation. International Journal of Entrepreneurship and Innovation Management, 18(4), 289.

Hair, J. F., Ringle, C. M., Sarstedt, M., \& Vinzi, E. (2014). Editorial partial least squares structural equation modeling: Rigorous applications, better results and higher acceptance. Long Range Planning, $46(1-2), 1-12$.

Helfat, C. E., \& Peteraf, M. A. (2003). The dynamic resource-based view: Capability lifecycles. Strategic Management Journal, 24(10), 997-1010.

Hou, J.-J. (2008). Toward a research model of market orientation and dynamic capabilities. Social Behavior and Personality: An International Journal, 36(9), 1251-1268.

Jones Osasuyi, O., \& Mwakipsile, G. (2017). Working capital management and managerial performance 
in some selected manufacturing firms in Edo State Nigeria. Journal of Accounting, Business and Finance Research, 1(1), 46-55.

Kapmeier, F., \& Struben, J. (2017). Understanding the Dynamics of Alliance Capabilities. In Proceeding on 35th International Conference of the System Dynamics Society (pp. 1-28).

Kucukkocaoglu, G., \& Bozkurt, M. A. (2018). Identifying the effects of mergers and acquisitions on Turkish banks performances. Asian Economic and Financial Review, 6(3), 235-244.

Le, H. L., Vu, K. T., Du, N. K., \& Tran, M. D. (2018). Impact of working capital management on financial performance: The case of Vietnam. International Journal of Applied Economics, Finance and Accounting, 3(1), 15-20.

Lin, Y., \& Wu, L. Y. (2014). Exploring the role of dynamic capabilities in firm performance under the resource-based view framework. Journal of Business Research, 67(3), 407-413.

Loucks, J., Bradley, J., Macaulay, J., Noronha, A., \& Wade, M. (2015). Digital vortex: How digital disruption is redifining industries. Global Center for Digital Business Transformation, 1-24.

Malarvizhi, C. A., Nahar, R., \& Manzoor, S. R. (2018). The strategic performance of Bangladeshi private commercial banks on post implementation relationship marketing. International Journal of Emerging Trends in Social Sciences, 2(1), 28-33.

Maldonado-Guzman, G., Marin-Aguilar, J., \& Garcia-Vidales, M. (2018). Innovation and performance in Latin-American small family firms. Asian Economic and Financial Review, 8(7), 1008-1020.

Markides, C. (2006). Disruptive innovation: In need of better theory business-model innovation. Harvard Business Review, 23, 19-25.

Maroofi, F., Ardalan, A. G., \& Tabarzadi, J. (2017). The effect of sales strategies in the financial performance of insurance companies. International Journal of Asian Social Science, 7(2), 150-160.

Martelo, S., Barroso, C., \& Cepeda, G. (2013). The use of organizational capabilities to increase customer value. Journal of Business Research, 66(10), 2042-2050.

Menguc, B., Auh, S., \& Shih, E. (2007). Transformational leadership and market orientation: Implications for the implementation of competitive strategies and business unit performance. Journal of Business Research, 60(4), 314-321. 8

Mihardjo, L. W. W., \& Rukmana, R. A. N. (2018). Does digital leadership impact directly or indirectly on dynamic capability: Case on Indonesia telecommunication industry in digital transformation? The Journal of Social Sciences Research, 2, 832-841.

Mosbah, A., Serief, S. R., \& Wahab, K. A. (2017). Performance of family business in Malaysia. International Journal of Social Sciences Perspectives, 1(1), 20-26.

Mowlaei, M. (2017). The impact of AFT on export performance of selected Asian developing countries. Asian Development Policy Review, 5(4), 253-261.

Narver, J. C., \& Slater, S. F. (1990). The effect of market orientation on business profitability. Journal of Marketing, 54(4), 20-35. doi: 10.2307/1251757

Özşahin, M., Zehir, C., Acar, A. Z., \& Sudak, M. K. (2013). The effects of leadership and market orientation on organizational commitment. Procedia - Social and Behavioral Sciences, 99, 363-372.

Pisano, G. P. (2015). A normative theory of dynamic capabilities: Connecting strategy, know-how, and competition. HBS Working Paper, 16-036, 42.

Protcko, E., \& Dornberger, U. (2014). The impact of market orientation on business performance - The case of Tatarstan knowledge-intensive companies (Russia). Problems and Perspectives in Management, 12(4), 225-231.

Purnama, C. (2014). Improved performance through empowerment of small industry. Journal of Social Economics Research, 1(4), 72-86.

Racela, O. C. (2014). Customer orientation, innovation competencies, and firm performance: A proposed conceptual model. Procedia-Social and Behavioral Sciences, 148, 16-23.

Salunke, S., Weerawardena, J., \& McColl-Kennedy, J. R. (2011). Towards a model of dynamic capabilities in innovation-based competitive strategy: Insights from project-oriented service firms. Industrial Marketing Management, 40(8), 1251-1263.

Sandberg, J. (2014). Digital Capability: Investigating Coevolution of IT and Business Strategies. Doctoral Dissertation. 
Santhi, N. S., \& Gurunathan, K. B. (2014). Fama-French three factors model in Indian mutual fund market. Asian Journal of Economics and Empirical Research, 1(1), 1-5.

Sapienza, H. J., Zahra, S., \& Davidson, H. (2006). Entrepreneurship and dynamic capabilities: A review, model and research agenda ahaker. Journal of Management Studies, 43, 917-955.

Schoemaker, P. J. H., Heaton, S., \& Teece, D. (2018). Innovation, dynamic capabilities, and leadership. California Management Review, 61, 15-42.

Schweitzer, J. (2014). Leadership and innovation capability development in strategic alliances. Leadership \& Organization Development Journal, 35(5), 442-469.

Susanti, A. A., \& Arief, M. (2015). The effect of dynamic capability for the formation of competitive advantage to achieve firm's performance (Empirical study on Indonesian credit co-operatives). $A d$ vanced Science Letters, 21(4), 809-813.

Teece, D. J. (2014). A dynamic capabilities-based entrepreneurial theory of the multinational enterprise. Journal of International Business Studies, 45(1), 8-37.

Teece, D. J., Pisano, G., \& Shuen, A. (1997). Dynamic capabilities and strategic management. Strategic Management Journal, 18(7), 509-533.

Tidd, J. \& Bessant, J. R., (2013). Managing Innovation: Integrating Technological, Market and Organizational Change (5th ed.). John Wiley \& Sons.

Toduk, Y., \& Gande, S. (2016). What's Next In Turkey? A New Leadership Model for Connected Age. In Amrop Leadership Series (pp. 1-41).

Wasono, L. W., Furinto, A., \& Rukmana, R. A. N. (2018). The effect of dynamic, innovation, and alliances capability on sustainable competitive advantage in the digital disruption era for incumbent telecommunication firm. In Proceedings of the international conference on Industrial Engineering and Operations Management, 6-8, 2111-2121.

Yeow, A., Soh, C., \& Hansen, R. (2018). Aligning with new digital strategy: A dynamic capabilities approach. Journal of Strategic Information Systems, 27(1), 43-58.

Zhu, P. (2015). Digital Master: Debunk the Myths of Enterprise Digital Maturirity. Lulu Publishing Services.

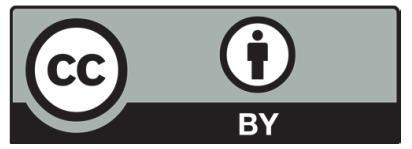

(C) 2019 by the authors; licensee Growing Science, Canada. This is an open access article distributed under the terms and conditions of the Creative Commons Attribution (CCBY) license (http://creativecommons.org/licenses/by/4.0/). 